\title{
VAPONA-LIUSKOISTA HAIHTUVAN DDVP:n MYRKYLLISYYS
}

\author{
Kurt HenRiksSON \\ Valtion eläinlääketieteellinen laitos, Helsinki \\ KaARlo Kallela \\ Eläinlääketieteellinen korkeakoulu, Helsinki \\ Matti Virtamo ja Pirkko Pfäffli \\ Työterveyslaitos, Helsinki
}

Saapunut 16. 5. 1971

\begin{abstract}
The purpose of the study was to clarify the toxicity to calves of the insecticide Vapona Strip $囚$. Besides 39 calves, the study involved 1 heifer, 7 sheep, 6 guinea pigs and 20 mice. The highest concentration of DDVP in the air, $2.1 \mathrm{mg} / \mathrm{m}^{2}$, was measured when the number of strips was highest or 16 times the recommended number. The concentration of DDVP in the air did not prove dangerous for the calves or the other animals in the study.
\end{abstract}

Tuhohyönteisten hävittämiseen kasvihuoneissa on DDVP:tä käytetty ruiskutteina ja kaasutteina (Dedevap »Bayer», Nogos-50 »Ciba») Suomessa 1961 lähtien. Vapona-liuskoissa sitä on hyönteisten torjunnassa käytetty 1969 alkaen. Eri muodoissa on DDVP:tä käytetty n. $2100 \mathrm{~kg}$ (M. Markkula, suullinen tiedonanto 21. 4. 1971).

Kemiallisesti DDVP (diklorvossi) on 0.0-dimetyyli-2.2-dikloorivinyylifosfaatti, jonka empiirinen kaava on $\mathrm{C}_{4} \mathrm{H}_{7} \mathrm{Cl}_{2} \mathrm{O}_{4} \mathrm{P}$ ja rakennekaava<smiles>COP(=O)(OC)OC=C(Cl)Cl</smiles>

Fysikaalisilta ominaisuuksiltaan aine on puhtaana lievän ominaishajun omaavaa nestettä, jonka tiheys on $1.42 \mathrm{~g} / \mathrm{cm}^{3}\left(25^{\circ} \mathrm{C}\right)$, sulamispiste $-18^{\circ} \mathrm{C}$ ja kiehumispiste $20 \mathrm{~mm} \mathrm{Hg}$ paineessa $140^{\circ} \mathrm{C}, 1 \mathrm{~mm} \mathrm{Hg}$ paineessa $84^{\circ} \mathrm{C}$. Höyrynpaine on $+32^{\circ} \mathrm{C}$ :ssa $0.032 \mathrm{~mm} \mathrm{Hg}$ 
ja $+60^{\circ} \mathrm{C}$ :ssa $0.296 \mathrm{~mm} \mathrm{Hg}$. Aine luetaan kohtalaisen voimakkaisiin myrkkyihin. Virallisen kasvinsuojeluaineluettelon (1969) mukaan DDVP:n $\mathrm{LD}_{50}$-arvo on rotalla suun kautta 25 - $30 \mathrm{mg} / \mathrm{kg}$ ja ihon kautta $75-900 \mathrm{mg} / \mathrm{kg}$.

Kärpästen, koiden, sääskien, ym. lentävien hyönteisten torjuntaan on DDVP:tä käytetty PVC-muovimassaan sekoitettuna useissa maissa vuosikausia. Tuotetta valmistaa Shell ns. Vapona-liuskoina (Vapona Strip (B), joissa DDVP:tä on n. $20 \%$. Tutkimusten mukaan tuotteen myrkyllisyys on näin käytettynä alhaisempi ja erilainen kuin teknisen DDVP:n. Tämä johtuu siitä, että tehoainetta vapautuu Vapona-liuskoista pieniä määriä pitkän ajan kuluessa, joten normaaleissa ympäristöolosuhteissa haihtuminen on »kontrolloitua».

Suomessa Vapona-liuskojen käyttö on ollut sallittua vuodesta 1969. Vuoden 1970 loppuun mennessä oli liuskoja myyty $65000-70000$ kappaletta (L. Iisakkila, suullinen tiedonanto 2. 3. 1971). Kaikkiaan oli vuoden 1970 alkuun mennessä Vapona-liuskoja eri puolilla maapalloa käytetty n. 100 miljoonaa kappaletta (n. 2 milj. kg DDVP:tä).

Valmisteen käytön suhteen on eri maissa hyvinkin erilaisia määräyksiä. Ruotsissa ja tiettävästi Yhdysvalloissa ei rajoituksia ole. Suomessa lienevät käyttörajoitukset ankarampia kuin missään muussa maassa. Niinpä valmistetta saadaan käyttää ainoastaan tiloissa, joissa ihmiset eivät jatkuvasti oleskele.

Selostettava tutkimus aiheutui epäilyksistä, joiden mukaan Vapona-liuskat olisivat aiheuttaneet myrkytyksiä kotieläimille, lähinnä vasikoille. Kun tiedot kirjallisuudessa vasikoiden herkkyydestä DDVP:n mahdollisille haittavaikutuksille ovat puutteellisia ja kun tiedetään niiden täysikasvuisia nautaeläimiä herkemmin reagoivan orgaanisten fosforihappoestereiden myrkkyvaikutuksille (ROSENBERGER 1970), katsottiin vasikat sopiviksi koe-eläimiksi tutkimukseen, jonka suorittamista puolsi myös Vapona-liuskojen uutuus Suomen markkinoilla ja käytännössä saatujen kokemusten puute.

\section{Kokeiden järjestely}

Koe suoritettiin Eläinlääketieteellisen korkeakoulun kotieläinhygienian laitoksella. Koehuoneena oli eläinosasto, jonka tilavuus oli n. $140 \mathrm{~m}^{3}$ ja korkeus n. $2.6 \mathrm{~m}$. Koehuoneen muut mitat, sisustus ja koeeläinten sijoittelu karsinoihin selviävät kuvasta 1 . Kuivikkeina eläimille käytettiin olkia ja turvepehkua.
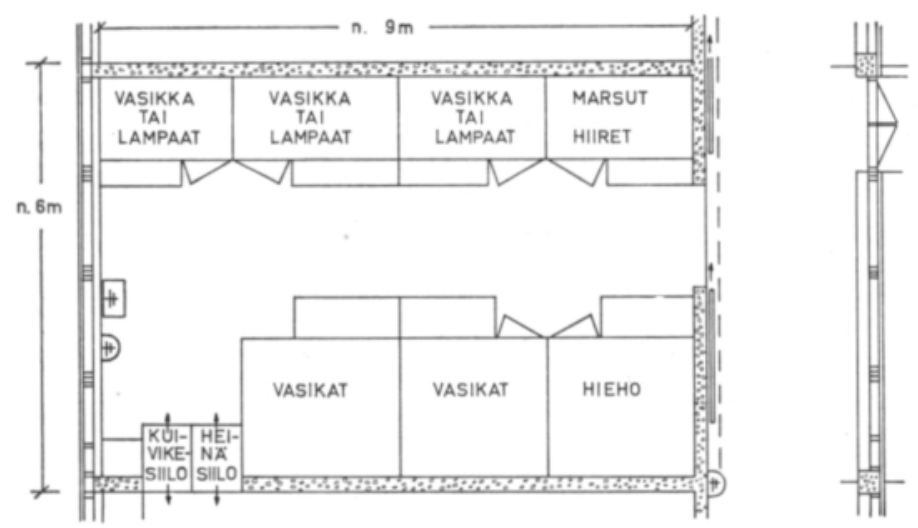

Kuva 1. Koetila ja eläinten sijoitus.

Fig. 1. Experiment premises and locations of animals. 
Normaalisti toimii eläinosaston ilmanvaihto ylipainejärjestelmän mukaan siten, että ilmavirta kulkee koehuoneeseen eläinosaston käytävästä oven kautta ja poistuu sen katossa olevien poistoventtiilien kautta. Koeajaksi pyrittiin ilmanvaihto järjestämään mahdollisimman epäedulliseksi. Oviaukko peitettiin tiiviisti muoviverholla ja kattoventtiilit suljettiin. Ainoana poistoaukkona toimi raollaan oleva pieni $(30 \times 65 \mathrm{~cm})$ ulkoseinäikkuna. Muutamia kertoja koejakson aikana jouduttiin yhtä kattoventtiileistä raottamaan lämmön ja kosteuden noustessa liian suureksi.

Kokeessa oli kaikkiaan 39 vasikkaa, 1 hieho, 7 lammasta, 6 marsua ja 20 valkoista hiirtä.

Vasikat hankittiin Karjakunnan eläinvälityksen kautta. Saapuessaan ne olivat keskimäärin 8 vrk:n ikäisiä ja 36 kg:n painoisia (taulukko 1). Vasikoista oli kolme mukana kokeessa koko sen kestoajan. Muut olivat koehuoneessa kolmen vasikan ryhmissä kokeen alkupuolella viikon, kokeen loppupuoliskolla kahden viikon ajan tietyn Vapona-liuskamäärän vaikutuksen alaisina.

Kokeen alkupuolella liuskojen lukua muutettiin viikoittain siten, että niitä koejakson ensimmäisellä viikolla oli valmistajan suosittelema määrä $\left(1\right.$ liuska/28 $\left.\mathrm{m}^{\mathrm{s}}\right)$ ja seuraavina viikkoina 2-, 4-, 6-, 10- ja 16kertaiset määrät. Ennen koehuoneeseen sijoittamista vasikat pidettiin viikon ajan laitoksen eräässä toisessa eläinhuoneessa.

Kokeen loppupuoliskolla Vapona-liuskojen lukumäärää vähennettiin viikoittain päinvastaisessa järjestyksessä. Vasikat sijoitettiin laitokselle saapumisensa jälkeen suoraan koehuoneeseen ja pidettiin ensin viikko yksittäiskarsinoissa ja sitten viikko yhteisessä kolmen vasikan karsinassa.

Koeajan päätyttyä vasikat siirrettiin toiseen huoneeseen, jossa niitä seurattiin vähintään yhden viikon ajan. Osa vasikoista jätettiin jälkitarkastukseen laitokselle yli kahden kuukauden ajaksi. Kokeessa koko ajan mukana olleita kolmea vasikkaa on kokeen päätyttyä tarkkailtu yli 15 viikkoa.

Kokeen alkupuoliskolla vasikat saivat ensimmäisen vuorokauden aikana sokeri-suolaliuosta. Tämän jälkeen annettiin piimää kahdesti vuorokaudessa, aluksi n. 2 1/vrk. Määrää nostettiin siten, että se viikon kuluttua oli $6 \mathrm{l} / \mathrm{vrk}$. Heinää oli vapaasti saatavissa. Kokeen loppupuoliskolla vasikoille annettiin piimää heti tulopäivästä lähtien, aluksi $11 /$ vrk ja viikon kuluttua n. $61 /$ vrk.

Hieho, joka kokeen alkaessa oli seitsemän kuukauden ikäinen ja $187 \mathrm{~kg}$ :n painoinen, oli koehuoneessa koko tutkimuksen ajan ja on jatkuvasti laitoksella. Lampaista oli uuhia kuusi ja pässejä yksi. Uuhet, yksi n. 3.5-vuotias, neljä n. 1.5-vuotiasta ja yksi n. 0.5-vuotias, oli joko juuri ennen koetta astutettu tai astutettiin sen alkupuolella edellä mainitulla pässillä, joka oli n. 0.5-vuotias. Lampaat siirrettiin toiseen huoneeseen koeajan puolivälissä, jolloin niiden tilat saatiin vasikoiden käyttöön (kuva 1).

Marsut oli jaettu kahteen häkkiin. Näistä toinen sijoitettiin $50 \mathrm{~cm}: n$ ja toinen $100 \mathrm{~cm}: n$ korkeudelle.

Hiiristä oli koiraita 10. Nämä sijoitettiin lasiastiaan $50 \mathrm{~cm}$ :n korkeudelle. Naaraat, joita oli myös 10 , olivat $100 \mathrm{~cm}: n$ korkeudessa. Kokeen 43. vuorokautena kolme naarasta ja yksi uros eristettiin yhteen purkkiin $50 \mathrm{~cm}$ :n korkeudelle. Kun naaraat todettiin kantaviksi, ne siirrettiin omiin häkkeihinsä $50 \mathrm{~cm}: \mathrm{n}$ korkeuteen ja uros takaisin urosten joukkoon. Hiiret synnyttivät seuraavasti:

\begin{tabular}{|c|c|c|c|}
\hline Emä 2 & $"$ & 63. & 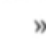 \\
\hline mä 3 & $"$ & 64. & $»$ \\
\hline
\end{tabular}

Hiirten ruokinta oli sikäli normaalista poikkeavaa, että ne saivat pääasiallisesti teuraskarjalle tarkoitettua raerehua ja ainoastaan rajoitetusti hiiri- ja rottarehua.

Vapona Strip ${ }^{\circledR}$-liuskat olivat 10 liuskaa käsittävissä pakkauksissa. Jokainen liuska oli lisäksi omassa ilmatiiviissä myyntipäällyksessä, joka avattiin ripustamisen yhteydessä. Liuskoissa oli Shellin tavaramerkki ja merkintä "Contains Vapona Insecticide AC 6750". Liuskat ripustettiin n. 2 m lattiasta koehuoneen pituussuunnassa olevalle kahdelle vaijerille tasaisin välein. Taulukosta 2 ilmenevät liuskojen viikottaiset lukumäärät koehuoneessa.

Kokeen päätyttyä määritettiin käyttämättömän sekä koko kokeen ajan (n. 3 kk) käytössä oleen liuskan DDVP-pitoisuus. Edellisen liuskan todettiin sisältävän $18.8 \%$ ja jälkimmäisen 13.1 \%. DDVP:tä.

Koehuoneen lämpötila mitattiin katon rajaan sijoitetulla piirtävällä lämpömittarilla (Wilh. Lambrecht, tyyppi 251). Lisäksi lämpötilaa kontrolloitiin kolmella eri puolille koehuonetta sijoitetulla elohopeamittarilla. Vuorokautinen keskilämpö (kuva 2) on määritelty piirturin mittaaman käyrän kahden tunnin välein osoittamien lämpötilojen keskiarvona. 
Suhteellinen kosteus mitattiin piirtävällä hiuskosteusmittarilla (Wilh. Lambrecht, tyyppi 250) huoneen ikkunanpuoleisessa päässä. Vuorokautinen suhteellisen kosteuden keskiarvo (kuva 2) on laskettu mittarin piirtämän käyrän kahden tunnin välein osoittamien lukemien keskiarvona.

DDVP-pitoisuus mitattiin eräin poikkeuksin yhden ja viiden vuorokauden kuluttua siitä, kun liuskamäärää oli muutettu (taulukko 2). Täten liuskojen määrä oli sama kahden peräkkäisen mittauskerran aikana.

DDVP absorboitiin veteen ilmasta. Absorptioastioina käytettiin kaasun hajoitussintterillä varustettuja pesupulloja, joita oli kytketty kaksi peräkkäin. Absorptionesteen määrä oli $25 \mathrm{ml}$ pulloa kohden ja ilman virtaus $1 \mathrm{l} / \mathrm{min}$. Näytteenottoaika vaihteli 60-120 minuuttiin. Ilmapumppuina käytettiin Reciprotor-mäntäpumppuja (valmistaja Reciprotor A/S, Danmark). Näyteilman tilavuus mitattiin suoraan osoittavalla kaasumittarilla.

DDVP:n määrittäminen vesiliuoksesta (HuGHEs 1963, modif.) perustuu dikloorivinyylidimetyyliidifosfaatin hydrolysoitumiseen alkaalisessa vesiliuoksessa diklooriasetaldehydiksi, joka määritetään 2.4-dinitrofenyylihydratsoninaan kolorimetrisesti.

Reagenssit:

1. $1.2 \mathrm{~N}$ natriumhydroksidiliuos

2. $0.1 \% 2.4$-dinitrofenyylihydratsiniliuos ( $4 \mathrm{~N} \mathrm{HCl}: s s a)$

3. $4 \mathrm{~N}$ natriumhydroksidiliuos

4. Etanoli

5. 2.2-dikloorivinyylidimetyylifosfaatti (Vapona Analytical Standard, $94.4 \%$, Shell)

Absorptioliuoksesta otetaan $5 \mathrm{ml}: \mathrm{n}$ näyte $10 \mathrm{ml}: \mathrm{n}$ mittapulloon, joka sitten upotetaan jäihin. Kun näytteen lämpötila on $0^{\circ} \mathrm{C}$, lisätään siihen $1 \mathrm{ml} 1.2 \mathrm{~N} \mathrm{NaOH}$ :a, jonka lämpötila on myös $0^{\circ} \mathrm{C}$. Sekoitetaan ja pidetään $0^{\circ} \mathrm{C}: n$ lämpötilassa vielä täsmälleen $15 \mathrm{~min}$. Lisätään $0.6 \mathrm{ml} 0.1 \%$ 2.4-dinitrofenyylihydratsiniliuosta, sekoitetaan, ja näyte siirretään $37^{\circ} \mathrm{C}$ vesihauteeseen $60 \mathrm{~min}$. ajaksi. Lisätään $0.6 \mathrm{ml}$ $4 \mathrm{~N} \mathrm{NaOH}: a$, sekoitetaan, ja pullo täytetään etanolilla merkkiin $(10 \mathrm{ml})$.

Liuoksen aiheuttama valon absorptio mitataan aaltopituudella $575 \mathrm{~nm}$ käyttäen vertailuliuoksena liuosta, jossa on kaikki reagenssit mutta ei DDVP:tä.

Standardisuora valmistetaan käyttäen tunnettuja määriä dikloorivinyylidimetyylifosfaattia käsiteltyinä samoin kuin näytteet.

Standardeihin käytetään vesiliuoksia, joissa on $8-32 \mu \mathrm{g}$ dikloorivinyylidimetyylifosfaattia/10 ml. Standardisuora on valmistettava aina uudestaan samanaikaisesti näytteiden kanssa. Dikloorivinyylidimetyylifosfaatin vesiliuokset säilyvät muuttumattomina noin kaksi päivää.

Vesiliuoksessa dikloorivinyylidimetyylifosfaatti voidaan määrittää vielä pitoisuudesta $0.4 \mu \mathrm{g} / \mathrm{ml}$, ilmanäytteistä vielä pitoisuudesta $0.1 \mu \mathrm{g} / 1\left(=0.1 \mathrm{mg} / \mathrm{m}^{3}\right)$, jos näyteilman tilavuus on $\mathrm{n} .100 \mathrm{l}$.

Hiilidioksidi-, rikkivety- ja ammoniakkipitoisuudet mitattiin kaasuilmaisinputkilla (valmistaja Drägerwerk AG, Lübeck). Mittaus perustuu tutkittavan kaasun ja putken täytteenä olevan reagenssin väliseen värinmuutosreaktioon. Pitoisuus luetaan suoraan putkessa olevalta mitta-asteikolta.

Happimittaukset tehtiin suoraan osoittavalla hapen paramagnetismiin perustuvalla laitteella "Beckman Oxygen Analyzer Model D2 S» (valmistaja Beckman Instruments Ltd., USA).

DDVP:n tai sen hajoamistuotteiden toteamiseksi suoritettiin vasikoiden verestä analyysejä ajankohtina, jolloin koehuoneessa oli vajaan viikon ajan ollut valmistajan suosittelemiin määriin verrattuna kaksi-, kuusi- ja kuusitoistakertainen määrä Vapona-liuskoja. Analyysit suoritettiin kunakin kertana kahdesta koko kokeen ajan mukana olleesta vasikasta sekä kahdesta vasikasta, jotka olivat ennen verinäytteen ottoa olleet kyseisissä väkevyyksissä kuusi vuorokautta. Lisäksi analysoitiin vertailyryhmän saamiseksi neljän vasikan verinäytteet ennen kokeen alkua. Näiden joukossa olivat myös edellä mainitut kaksi koko kokeen ajan mukana ollutta vasikkaa.

Analyysimenetelmä perustuu DDVP:n rasvaliukoisuuteen ja klooripitoisuuteen. Verinäytteistä uutettu rasva puhdistettiin ohutkalvokromatografiaa käyttäen, ja puhdistettu uute analysoitiin EC-detektorilla varustetulla kaasukromatografialaitteella. Vertailuna käytettiin vastaavalla tavalla valmistettua Vaponaliuskauutetta.

Eläintenhoitajien veriseerumin koliiniesteraasiaktiivisuus määritettiin kokeen alkupuolella kolmena ajankohtana, jolloin liuskoja oli koehuoneessa valmistajan suosittelema, 6- ja 16-kertainen määrä. Hoi- 
tajat olivat koehuoneilmassa keskimäärin n. 2 t/vrk. Vastaava määritys suoritettiin kuudesta vasikasta ajankohtana, jolloin liuskoja oli koehuoneessa $80 \mathrm{kpl}$ eli 16 kertaa suositeltu määrä. Vasikoista oli kaksi ollut koko ajan koehuoneessa, kaksi kuusi vuorokautta mainitussa väkevyydessä ja kaksi ei ollut lainkaan ollut DDVP:n vaikutuksen alaisena. Seerumin koliiniesteraasiaktiivisuus-määritykset tehtiin DE LA HUERGA et al:n (1952) menetelmän mukaan.

\section{Tulokset}

Kokeen aikana seurattiin vasikoiden painon kehitystä. Taulukosta 1 ilmenevät kunkin kolme vasikkaa käsittävän tuloerän keskimääräiset tulopainot, saapumisesta kuluneiden 19 vuorokauden keskimääräiset painot ja keskimääräinen vuorokautinen painonlisäys tänä aikana. Ensimmäisen tulopäivän vasikat muodostavat kaksi kolmen vasikan ryhmää, joista ensimmäinen käsittää ne vasikat, jotka olivat kokeessa koko koeajan (26. 10. 7026. 1. 71) eli 92 vuorokautta.

Kokeen alkupuoliskolla (erät 23. 10.-27.11.70) vasikoilla oli yleensä saapumisen yhteydessä ripuli, joka kesti n. viikon ajan. Ripulikautena painot laskivat usein tulopainon alapuolelle (suurin lasku $5.0 \mathrm{~kg}$ ). 30.10. 70 saapuneesta erästä kuoli yksi vasikka, joten tämän erän arvot taulukossa 1 koostuvat vain kahden vasikan keskiarvoista. Kuolleen vasikan ruumiinavaus osoitti sen menehtyneen Escherichia colin aiheuttamaan suolistotulehdukseen. Vasikka oli myös heikosti kehittynyt. Taulukosta 3 ilmenevät koko kokeen ajan koetilassa olleiden vasikoiden sekä kolmen muun koevasikan painonkehitykset 120 vuorokauden ikään mennessä. Vertailuna ovat laitoksessa syntyneiden ja kokeen ulkopuolella olleiden yhdeksän vasikan vastaavien lukujen keskiarvot.

Hiehossa ja lampaissa ei todettu kokeen kuluessa normaalista poikkeavaa. Hiehon paino lisääntyi kokeen aikana $55 \mathrm{~kg}$.

Hiiristä kuoli kokeen alkupuolella neljä kappaletta. Kokeen aikana astutetut 3 naarashiirtä synnyttivät yhteensä 23 normaalia poikasta tavanomaisen tiineysajan jälkeen. Poikasista kuoli ensimmäisen elinviikon aikana yksi.

Marsut kuolivat kaikki 10-15 vrk:n kuluttua kokeen päättymisestä viikon sisällä. Kuolemansyyksi todettiin Salmonella typhimurium var. copenhagen-tartunnan aiheuttama äkillinen suolistotulehdus.

Koetilan ilman kemiallisissa ja fysikaalisissa ominaisuuksissa tutkimuksen kuluessa tapahtuneet muutokset on esitetty taulukossa 2 ja kuvassa 2. Lämpötila koetilassa oli jokseenkin vakio ja keskimäärin $21.7^{\circ} \mathrm{C}$. Suhteellinen kosteus vaihteli laajalti vuorokauden sisälläkin (45-95\%). Korkea suht. kosteus ilmeni mm. koevasikoiden hikoilemisena. Varsinkin kuivikkeiden vaihdon ja karsinoiden pesun yhteydessä suht. kosteus nousi.

Hiilidioksidin pitoisuus koetilassa oli koko ajan verrattain korkea. Pienin mittaustulos oli $1100 \mathrm{~cm}^{3} / \mathrm{m}^{3}$ ja suurin $4300 \mathrm{~cm}^{3} / \mathrm{m}^{3}$. Ammoniakin pitoisuus oli ajoittain suurehko $\left(20-30 \mathrm{~cm}^{3} / \mathrm{m}^{3}\right)$. Rikkivetyä ei ilmassa todettu (mittausmenetelmän erotusraja on $\mathrm{n}$. $\left.2 \mathrm{~cm}^{3} \mathrm{H}_{2} \mathrm{~S} / \mathrm{m}^{3}\right)$. Ilman happipitoisuus oli normaali.

Vapona-liuskojen määrä ja niiden aikaansaama DDVP-pitoisuus kahdesti viikossa mitattuina ilmenevät taulukosta 2. Eri liuskamäärien aiheuttamat ilman DDVP-pitoisuudet ovat havainnollistettuina kuvassa 3 . Korkein pitoisuus, $2.1 \mathrm{mg} / \mathrm{m}^{3}$, todettiin suurimman Vapona-liuskamäärän ripustamisen jälkeen tehdyn mittauksen yhteydessä.

Kokeen alkupuoliskolla, jolloin tuoreita liuskoja lisättiin, väheni ilman DDVP-pitoisuus saman liuskamäärän ensimmäisen ja toisen mittauskerran välillä. Muutos ei ollut 


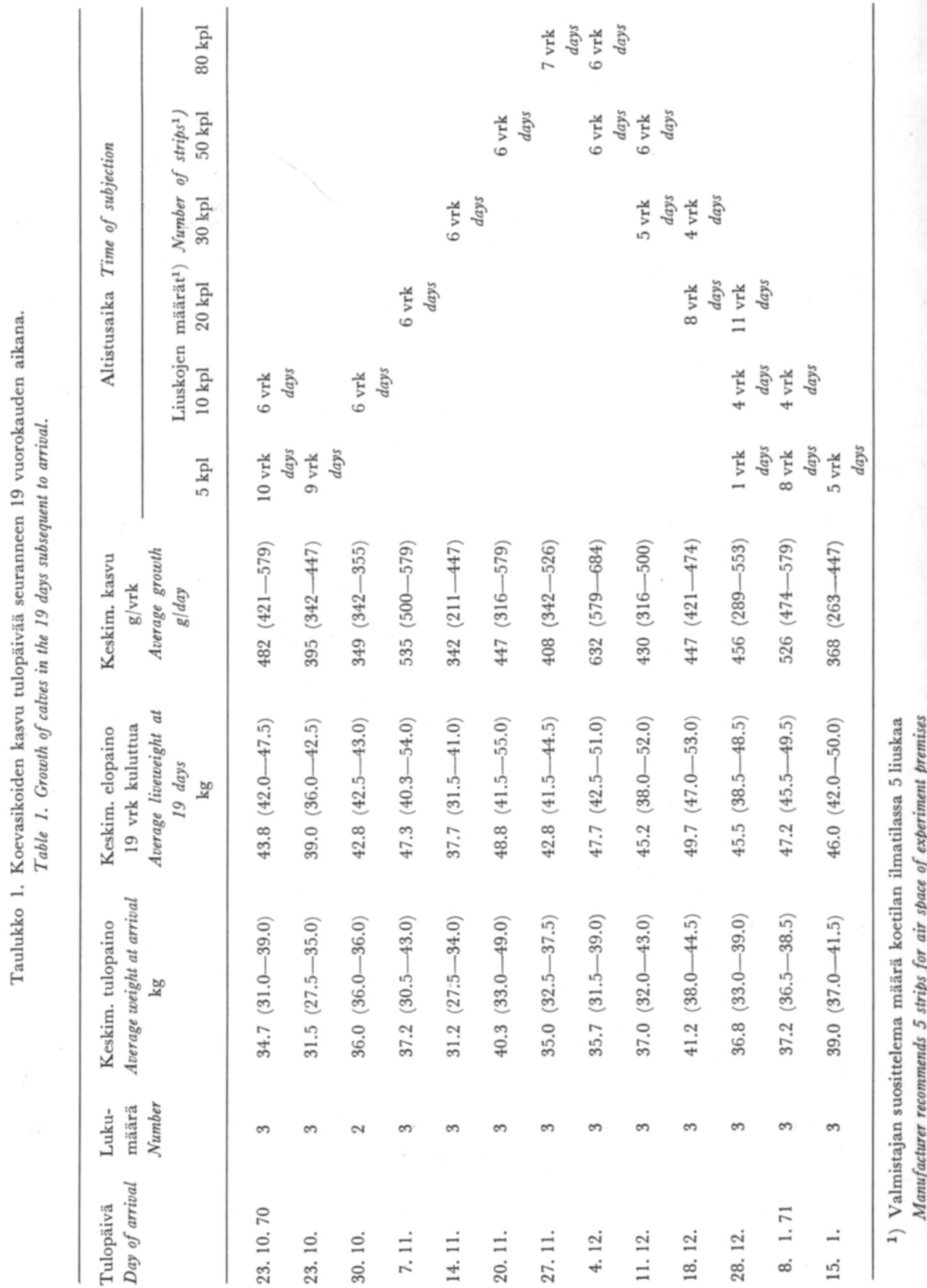




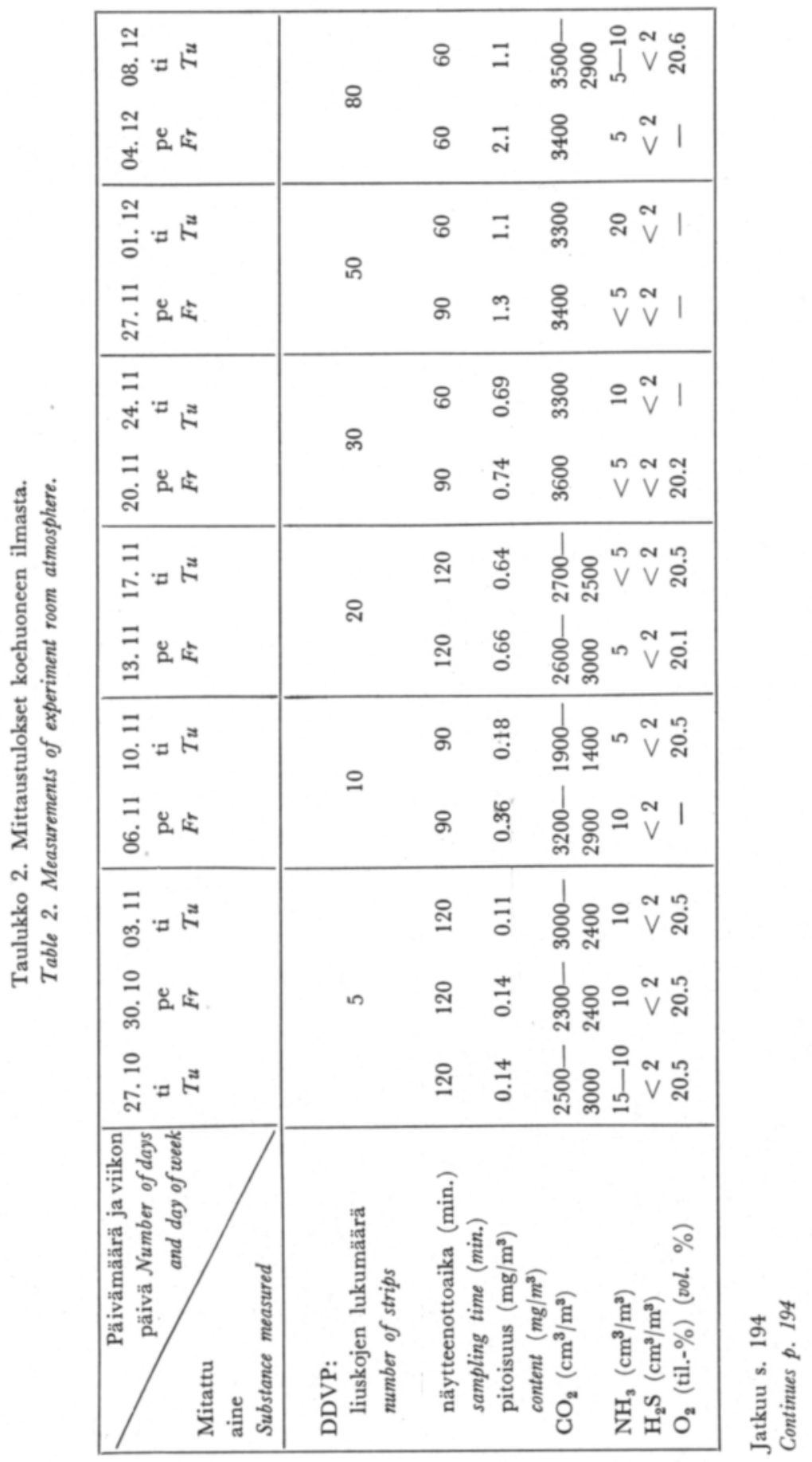




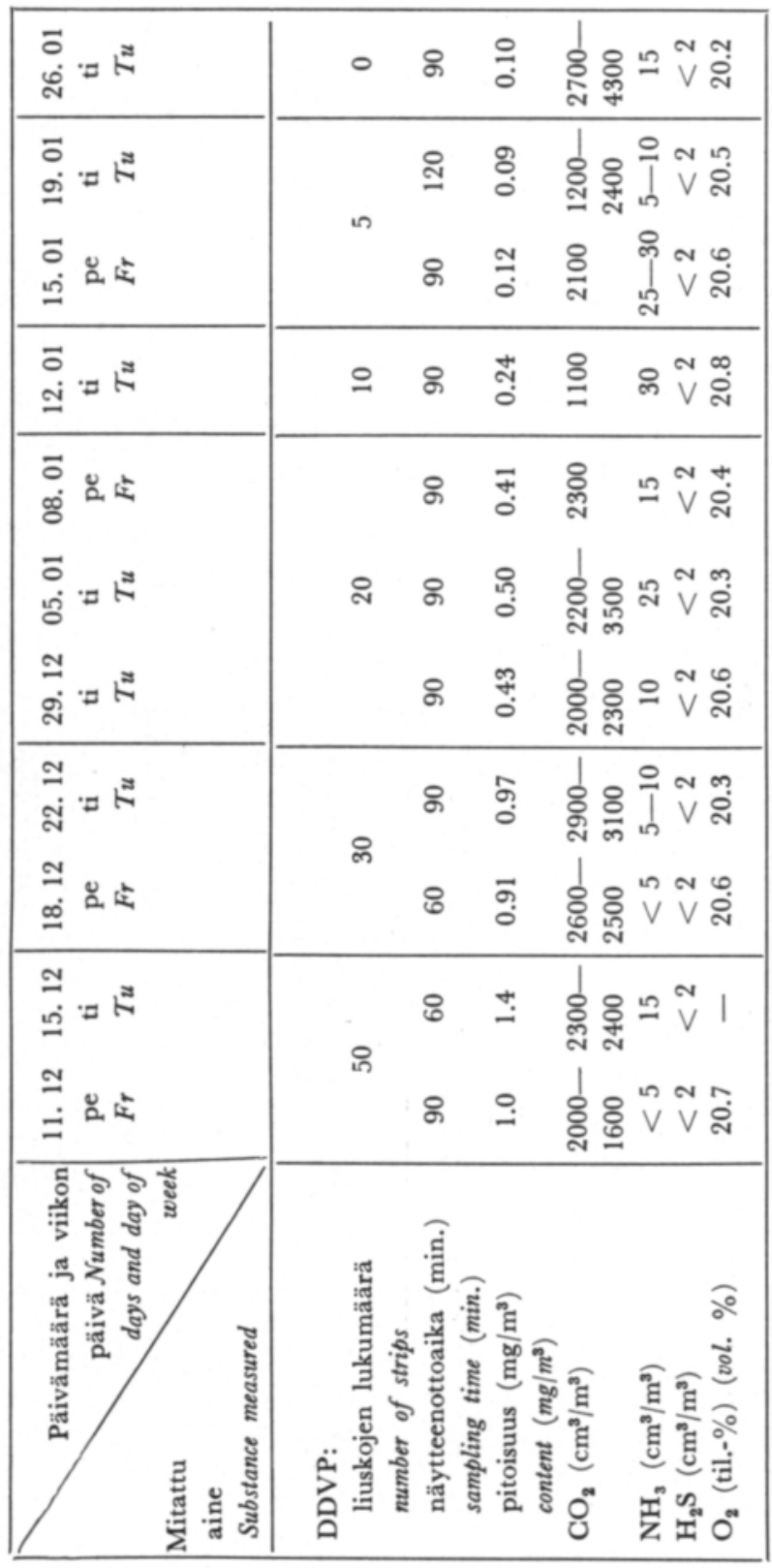

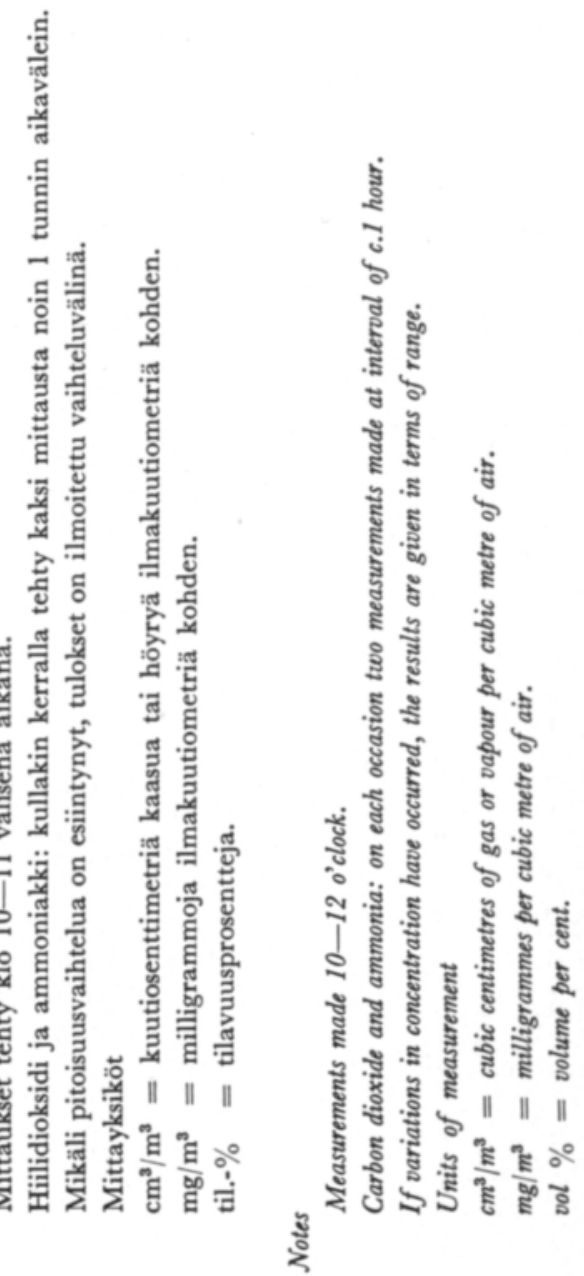




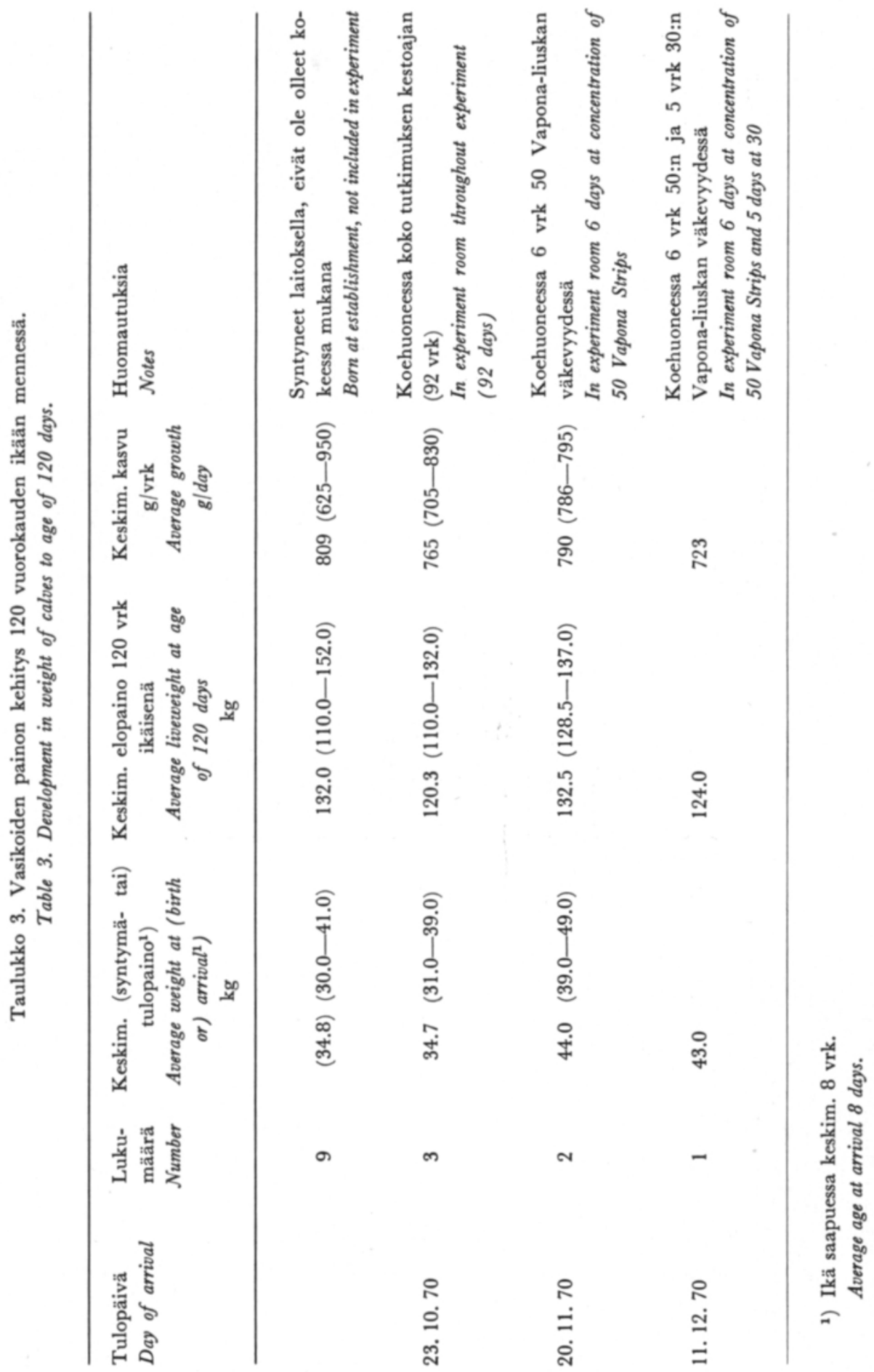




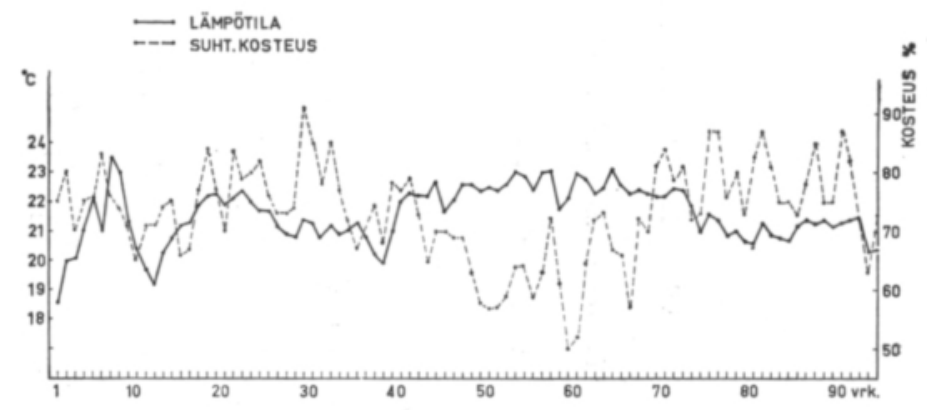

Kuva 2. Koetilan lämpötila ja suhteellinen kosteus.

Fig. 2. Tempernture and relative humidity of experiment premises.

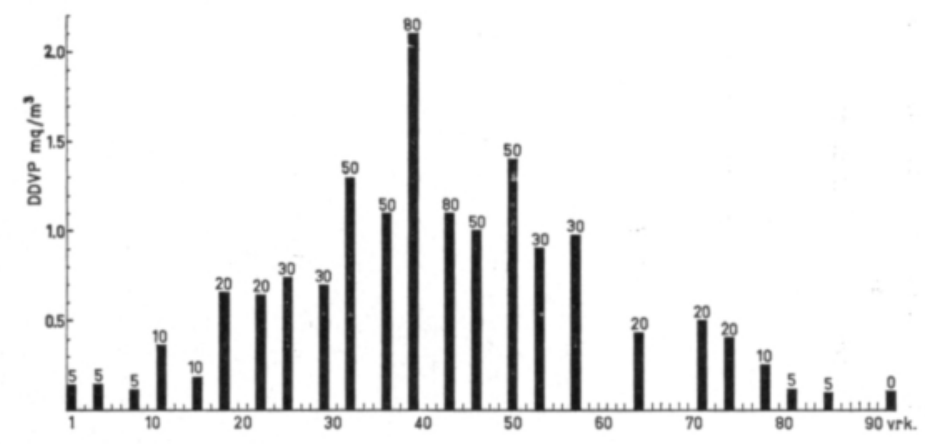

Kuva 3. DDVP:n pituisuusvaihtelu Vapona liuskojen annostuksen muuttuessa (liuskojen lukumäärä merkitty pylvään kärkeen).

Fig. 3. Variation in DDVP content with varying dosage of Vapona strips (number of srips shown at top of column).

säännöllinen loppupuolella, jolloin liuskoja vastaavasti poistettiin. Lisättäessä liuskoja, varsinkin lisäyksessä 50:stä 80:een, todettiin suhteellisen selvä pistävä haju sekä limakalvoja ärsyttävä vaikutus, joka kuitenkin vuorokauden parin sisällä huomattavasti heikkeni. Hengitystä ärsyttävä vaikutus ilmeni myös koevasikoissa, joilla suurimman liuskamäärän $(80 \mathrm{kpl})$ aikana oli hetkellistä hengenahdistusta.

Vasikoiden verinäytteistä suoritetut kaasukromatograafiset DDVP:n ja sen mahdollisten hajoamistuotteiden analyysit olivat kaikki kielteisiä. Koliiniesteraasin aktiivisuus eläinhoitajien ja vasikoiden seerumissa on esitetty taulukossa 4. Normaaliaktiivisuus käytetyn menetelmän mukaan on ihmisellä $130-310 \mu$ moolia/ml seerumia/tunti. 
Taulukko 4. Seerumin koliiniesteraasin aktiivisuus ( $\mu$ moolia/ml seerumia/tunti).

Table 4. Serum cholinesterase activity $(\mu \mathrm{mols} / \mathrm{ml}$ serum/hr $)$.

\begin{tabular}{|c|c|c|c|c|c|}
\hline $\begin{array}{l}\text { Vapona-liuskojen määrä } \\
\text { Number of Vapona Strips }\end{array}$ & 0 & 5 & 30 & 80 & Huomautuksia \\
\hline $\begin{array}{l}\text { Vrk kokeen alusta } \\
\text { Days after experiment started }\end{array}$ & - & 1 & 30 & 45 & Notes \\
\hline $\begin{aligned} & \text { Eläintenhoitaja } 1 . \\
& \text { Keeper } 1 .\end{aligned}$ & - & 160 & 200 & 245 & Koehuoneessa keskim. 2 t. vuorokaudessa \\
\hline $\begin{array}{r}\text { Eläintenhoitaja } 2 . \\
\text { Keeper } 2 .\end{array}$ & - & 125 & 170 & 215 & In experiment room on average 2 hours per day \\
\hline $\begin{array}{l}\text { Vasikka } 801 \\
\text { Calf }\end{array}$ & - & - & - & 85 & $\begin{array}{l}\text { Koehuoneessa kokeen alusta lähtien } \\
\text { In experiment room since start of experiment }\end{array}$ \\
\hline $\begin{array}{l}\text { Vasikka } 802 \\
\text { Calf }\end{array}$ & - & - & - & 80 & \\
\hline $\begin{array}{l}\text { Vasikka } 1901 \\
\text { Calf }\end{array}$ & - & - & + & 85 & $\begin{array}{l}\text { Koehuoneessa } 6 \text { vrk } 80 \text { Vapona-liuskan } \\
\text { väkevyydessä }\end{array}$ \\
\hline $\begin{array}{l}\text { Vasikka } 1903 \\
\text { Calf }\end{array}$ & - & - & - & 85 & $\begin{array}{l}\text { In experiment room } 6 \text { days at concentration of } \\
80 \text { Vapona Strips }\end{array}$ \\
\hline $\begin{array}{l}\text { Vasikka } \quad 8 \\
\text { Calf }\end{array}$ & 80 & - & - & - & $\begin{array}{l}\text { Vertailueläimet } \\
\text { Control animals }\end{array}$ \\
\hline $\begin{array}{ll}\text { Vasikka } & 9 \\
\text { Calf } & \end{array}$ & 85 & - & - & - & \\
\hline
\end{tabular}

- ei määritelty

- not determined

\section{Tulosten tarkastelua}

Lukuisissa kokeissa on todettu Vapona-liuskojen (Vapona Strip®) suhteellinen vaarattomuus ihmisille (ZAvon \& KindeL 1966, CAvaGNA et al. 1969). Veren plasmassa on kuitenkin ilmennyt koliiniesteraasiaktiivisuuden laskua vuodepotilaissa, jotka olivat 0.2 $\mathrm{mg} / \mathrm{m}^{3}$ DDVP-kaasuväkevyydessä 24 tuntia vuorokaudessa. Spesifisen punasoluihin sidotun asetyylikoliiniesteraasin laskua ei käytännössä ole lainkaan todettu. Koeolosuhteissa aikaansaaduissa sangen korkeissa DDVP-pitoisuuksissa $\left(8.7-2.4 \mathrm{mg} / \mathrm{m}^{3}\right)$ on tosin ilmennyt koehenkilöiden punasolujenkin koliiniesteraasin aktiivisuuden vähenemistä, mutta jo viikon kuluttua arvot palautuivat normaaleiksi. Vastasyntyneet eivät ole aikuisia herkempiä DDVP:n vaikutuksille.

Normaaliolosuhteissa suosituksen mukaisia Vapona-määriä (1 liuska/28 $\mathrm{m}^{3}$ ) käytettäessä DDVP-määrä harvoin ylittää $0.05 \mathrm{mg} / \mathrm{m}^{3}: \mathrm{n}$ rajan. Joskus se voi kuitenkin nousta aina $0.2 \mathrm{mg} / \mathrm{m}^{3}$ määrään (CAVAGNA et al. 1969). Höyrystymiseen vaikuttavat ilman fysikaaliset ominaisuudet, kuten lämpötila, kosteus ja ilmanpaine. Työpaikan ilmassa jatku- 
vassa päivittäisessä työssä (8 t/vrk) suositellaan sallittavaksi enintään $1 \mathrm{mg}$ DDVP:tä/m³ (Threshold Limit Values 1970).

DDVP-kokeiden ja Vapona-liuskojen käytön yhteydessä saatujen kokemusten perusteella on todettu, että valmisteen turvallisuusmarginaali on suuri ja että se suositusten mukaisesti käytettynä on vaaraton useille koti-, lemmikki- ja koe-eläimille. (TRACY et al. 1960). Eräille trooppisille akvaariokaloille ja häkkilinnuille liuskat voivat olla vaarallisia, jos ne on ripustettu eläinten välittömään läheisyyteen (LütHGEN \& LucAs 1971).

Useista koe-eläimillä suoritetuista kokeista mainittakoon koe (Mello 1967), jossa rottia pidettiin 63 vuorokautta ilmatilassa, jossa Vapona-liuskojen määrä suositeltuun määrään verrattuna oli 280-kertainen. Kliinisiä myrkytysoireita ei kokeen aikana tai sen jälkeen rotissa todettu. Ruumiinavauksissa ei myöskään ilmennyt DDVP:n vaikutuksesta johtuvia muutoksia.

Nyt suoritetun tutkimuksen puitteissa käytettiin koehuoneessa vaihtuvia liuskamääriä $(5,10,20,30,50$ ja 80 liuskaa/140 m³). Liuskojen määrät olivat suositeltuun määrään verrattuna 1-, 2-, 4-, 6-, 10-ja 16-kertaiset. Vaikka koehuoneen ilmanvaihto oli pyritty järjestämään mahdollisimman epäedulliseksi, ei DDVP:n pitoisuus noussut 80 liuskan aikana korkeammaksi kuin $2.1 \mathrm{mg} / \mathrm{m}^{3}$. Ilmanvaihdon heikkoutta kokeessa osoittavat $\mathrm{mm}$. korkea $\mathrm{CO}_{2}$-pitoisuus, suhteellisen kosteuden korkeat arvot sekä vasikoiden jatkuva hikoileminen kokeen aikana.

Taulukossa 2 esitetyt saman liuskamäärän eri DDVP-pitoisuudet kokeen alkupuolella osoittavat, että tehoaineen höyrystyminen ilmeisesti on suurin heti liuskapakkauksen avaamisen jälkeen, koska mittaustulokset poikkeuksetta ovat suuremmat ensimmäisen mittauskerran yhteydessä. DDVP:n höyrystyminen lienee kuitenkin sangen hidasta, koska kolme kuukautta riippuneessa liuskassa todettiin vielä n. $70 \%$ alkuperäisestä tehoaineesta. Taulukosta 2 ja kuvasta 3 ilmenevät ilman DDVP-määrät osoittavat myös, että samat liuskamäärät liuskojen lisäämisen ja poiston yhteydessä johtavat likimain yhtäpitäviin ilman DDVP-pitoisuuksiin. Tämä osoittaa liuskojen pitkäikäisyyden niiden insektisidisen tehon suhteen samoin kuin sen, että DDVP:n höyrystyminen vakio-olosuhteissa on tasaista.

Kokeen alkupuolella suoritetut eläintenhoitajien koliiniesteraasin aktiivisuuden määritystulokset pysyivät normaalirajoissa. Tämä osoittaa, etteivät DDVP-pitoisuudet ilmassa aiheuttaneet seerumin koliiniesteraasin aktiivisuudessa häiriöitä. Tiedetään, että tämä aktiivisuus punasolujen spesifiseen asetyylikoliiniesteraasin aktiivisuuteen verrattuna mm. ihmisellä yleensä laskee aikaisemmassa vaiheessa orgaanisten fosforihappoestereiden vaikutuksesta. Suurimman ilman DDVP-pitoisuuden aikana suoritettu vasikoiden vastaavan seerumin koliiniesteraasin aktiivisuusmäärittely osoitti sen alhaiseksi ja kontrollivasikoihin verrattuna muuttumattomaksi. Useiden tutkimusten (esim. RADELEFF \& WoodWARD 1956, Dybing \& HJELle 1957) mukaan onkin nautaeläimillä plasma- tai seerumi- eli ns. pseudokoliiniesteraasin aktiivisuus sangen alhainen ja merkityksetön.

Kokeen aikana ei vasikoiden veressä kaasukromatograafisesti voitu osoittaa DDVP:tä tai sen hajoamistuotteita. Mahdollinen vereen imeytynyt DDVP on kuitenkin voinut hajota niin nopeasti, ettei sitä voitu osoittaa. Tunnettua onkin, että DDVP hajoaa nopeasti maksassa (TrACY 1960, TrACY et al. 1960). Metaboliittien LD $_{50}$-arvot ovat DDVP:n $\mathrm{LD}_{50}$-arvoja huomattavasti suuremmat (CAsIDA et al. 1962) eikä niillä ole koliiniesteraasin aktiivisuutta alentavaa tehoa. Kliinisiä oireita, jotka voisivat johtua DDVP-myrkytyksestä, ei todettu kokeen tai sitä seuranneen kontrollijakson aikana koe-eläimissä. Lukuun- 
ottamatta suhteellisen yleistä tulon yhteydessä esiintynyttä ripulia oli yleiskunto vasikoilla hyvä ja kehitys normaalia. Kuitenkin painon lisäys kontrolleihin verrattuna oli pienempi. Tämä johtunee osittain huonoista ympäristöolosuhteista ja osittain vasikoiden heikosta ja vaihtelevasta tulokunnosta. Viimeksi mainittu seikka aiheutti mm. sen, että usein kesti useita vuorokausia ennen kuin vasikoiden paino alkoi nousta. Vastaavia häiriötekijöitä ei omassa navetassa syntyneillä kontrollivasikoilla ole ollut.

Koetilassa olleet marsut kuolivat kokeen jälkeen Salmonella typhimurium-suolistotulehdukseen. Koska Salmonella typhimurium on patogeeni bakteeri mm. marsuille, koska kokeen loppumisesta oli kulunut jo yli 10 vuorokautta ja koska tiedetään, että DDVP on akuutisti vaikuttava ja nopeasti metabolisoituva myrkky (TRACY 1960, TRACY et al. 1960), voidaan ko. bakteeritartunta katsoa kuoleman syyksi.

Yhteenvetona voidaan todeta, ettei suositusta 16 kertaakaan suurempi Vapona-liuskamäärä aiheuttanut myrkytyksiä kokeessa, jossa mm. pyrittiin aikaansaamaan mahdollisimman epäedullinen ilmanvaihto. Näin ollen näyttää ilmeiseltä, ettei Vapona Strip ß-valmiste suosituksen mukaan käytettynä voi aiheuttaa haittavaikutuksia normaaleissa kasvuolosuhteissa vasikoille ja että valmisteen turvallisuusmarginaali on riittävä.

\section{KIRJALLISUUS}

Casida, J. E., McBride, L. \& Niedermeier, R. P. 1962. Metabolism of 2,2-dichlorovinyl dimethyl pho phate in relation to residues in milk and mammalian tissues. J. Agric. Fd Chem. 10: 370-377

Cavagna, G., Locati, G. \& Vigliani, E. C. 1969. Clinical effects of exposure to DDVP (Vapona) insecticide in hospital wards. Archs Environ. Hlth 19: 112-123.

Dybing, O. \& HJelle, A. 1957. Kolinesteraseaktiviteten i blod hos storfe. Nord. VetMed. 9: 41-48. de la Huerga, J., Charlotte Yesinick \& Popper, H. 1952. Colorimetric method for the determination of serum cholinesterase. Am. J. Clin. Path. 22: 1126-1133.

Hugres, J. T. 1963. Colorimetric determination of low concentrations of 2,2-dichlorovinyl dimethyl phosphate in the atmosphere. Analyst 88: 318-319.

Kasvinsuojeluaineluettelo 1969. Kasvinsuoj. Seur. Julk. 39: 1-101.

KNAPP, F. W. \& Graden, A. P. 1964. Accidental exposure of dairy cows to excessive amount of dichlorvos. J. Econ. Ent. 57: 790-791.

Lüthgen, W. \& Lucas, H. 1971. Vergiftungen von Ziervögeln durch DDVP (Dichlorvos) bei der Ektoparasiten- und Schädlingsbekämpfung. Verhandlungsbericht des XIII Internationalen Symposiums über die Erkrankungen der Zootiere, p. 191- 194. Helsinki.

Melzo, D. 1967. Verficaco de toxicidade, para ratos brancos, do dichlorvos (DDVP) sob a forma de vaporizntes. Biologico (Sao Paulo) 33: 204-206.

RAdeleff, R. D. \& Woodard, G. T. 1956. Cholinesterase activity of normal blood of cattle and sheep. Vet. Med. 51: 512-514.

Rosenberger, G. 1970. Krankheiten des Rindes. Berlin und Hamburg.

Threshold limit values of airborne contaminants for 1970, 1970. American conference of governmental industrial hygienists, $1-27$.

Tracy, R. L. 1960. Insecticidal and toxicological properties of DDVP. Soap Chem. Spec. 36: 74-76, 105.

—- Woodcock, J. G. \& Chodroff, S. 1960. Toxicological aspects of 2,2-dichlorovinyl dimethyl phosphate (DDVP) in cows, horses and white rats. J. Con. Ent. 53: 593 - 601.

Zavon, M. R. \& Kindel, E. A. jr. 1966. Potential hazard in using dichlorvos insecticide resin. Adv. Chem. Ser. 60: 177-186. 


\title{
SUMMARY
}

THE TOXICITY OF DDVP (DICHLORVOS) EVAPORATED FROM VAPONA STRIP®

\author{
Kurt Henriksson
}

State Veterinary Medical Institute, Helsinki

KaARlo Kallela

College of Veterinary Medicine, Helsinki

Matti Virtamo and Pirkko Pfäffli

Institute of Occupational Health, Helsinki

The experiment comprised 39 calves, three of which were exposed to DDVP evaporation during the whole period, i.e. about three months. The number of the strips was varied, the recommended number in the experiment room (about $140 \mathrm{~m}^{3}$ ) being multiplied during the first half of the study by 1, 2, 4, 6, 10, and 16. The additions took place once a week. During the second half of the study the number of strips was correspondingly reduced.

In addition to the three calves which were kept in the experiment room during the whole study, another group of three calves was subjected to every alteration in the number of strips. Each of these groups was kept in the room for one week during the first half of the study and for two weeks during the second half.

Besides the calves, the study involved 1 heifer, 6 guinea pigs, and 20 mice. Three mice were mated and bore normal litters during the experiment. The study also involved 7 sheep, which were removed from the experiment room to an environment free of Vapona when the number of strips was highest (80).

The ventilation in the experiment room was kept at a minimum. The temperature and relative humidity were observed during the study. The temperature was rather constant, approx. $21.7^{\circ} \mathrm{C}$. The relative humidity varied $\left(45-95 \%\right.$ ) and was often high. The concentrations of DDVP, $\mathrm{CO}_{2}, \mathrm{H}_{2} \mathrm{~S}, \mathrm{NH}_{3}$, and $\mathrm{O}_{2}$ in the air were measured twice a week, i.e. twice in connection with each number of strips. During the recommended number of strips the concentration of DDVP in the air was $0.09-0.14 \mathrm{mg} / \mathrm{m}^{3}$. The highest concentration, $2.1 \mathrm{mg} / \mathrm{m}^{3}$, was measured when the number of strips was 16 times the recommended number. The $\mathrm{CO}_{2}$ content of the air was $2-8$-fold $\left(1100-4300 \mathrm{~cm}^{3} / \mathrm{m}^{3}\right)$ compared with normal, pure air. The $\mathrm{NH}_{3}$ content was at times rather high $\left(20-30 \mathrm{~cm}^{3} / \mathrm{m}^{3}\right)$, whereas the $\mathrm{O}_{2}$ content was normal. The $\mathrm{H}_{2} \mathrm{~S}$ was never ascertained. During the study period the DDVP content of the strips used for three months was reduced by 30 per cent.

The DDVP content of the blood of the calves was measured by means of gas chromatography, with negative results, at 2,6 , and 16 times the recommended number of strips.

The serum cholinesterase activity (SCA) of the keepers of the animals was observed during the first half of the study and was found to keep within normal values. The SCA of the calves was measured at the highest number of strips, the values did not differ from those of the control calves.

No symptoms of DDVP intoxication could be observed during or after the experiment in the calves or the other animals. When the number of strips was highest (16 times the recommended number) there was a temporary pungent smell in the air which had a slightly irritating effect on the mucuous membranes of the keepers and caused momentary symptoms of dyspnea in some of the calves. The gain in weight of the calves was also recorded and did not differ from normal.

When the number of strips was twice the recommended number, one of the calves died of Escherichia coli-gastroenteritis. Also four mice died during the study period; this can be regarded as a normal reduction. About two weeks after the experiment had ended, all the guinea pigs died of a Salmonella typhimurium infection.

In conclusion it can be stated that even when the number of Vapona Strips $®$ was sixteen times the recommended number, the concentration of DDVP in the air did not prove dangerous for the calves or the other animals involved in the study, although the ventilation was kept as low as possible. Thus it is obvious that Vapona Strip $®$ used in accordance with the recommendations does not have a detrimental effect on calves. 